\title{
LA POESIA DEL PADRE LUIS FELIPE NERI DE ALFARO
}

\author{
P O $~:$ \\ CIEMENTINA DIAZ Y DEOVANDO
}

Durante tres siglos, la poesia religiosa fué primigenia en Nueva España. Las frailes evangelizadores ensentaron la gravedad de los dogmas de la fe católica, con este recurso eficaz y objetivo. Autos Sacramentales y Coloquios cumplieron con tales enseñanzas, que con gran éxito continuan el presbítero Pedro Ramírez y Hernán González de Eslava durante el siglo xvr.

$Y$ apenas lo autóctono y lo adventicio se transfunden en nueva nacionalidad, don Fernando de Alva Ixtlilxdchitl canta al Sefior con imágenes indias $\mathbf{y}$ rerbo castellano.

$Y$ un siglo después, en el XVIr, el criollo y "erudito barroco" don Carlos de Sigitenza y Góngora escribe el Triunfo Parténico, compilación y resefía de los certámenes que en 1682 y 1683 realizb, en honor de la Immaculada Concepción de María, la Real y Pontificia Universidad de México. Piguraron en estos certámenes, al decir del cronista, más de quinientas composiciones, firmadas por los más exquisitos poetas de Nueva Esparia, extre otras, las de Sor Juana Inés de la Cruz. Esta monja criolla, pero 
mestiza por el sentimiento hacia su tierra mexicana, hace poemas con inclinaciones gongoristas o con gracia inimitable compone "tocotines", ambos sobre asuntos religiosos.

Los muchos poetas que en el siglo xvir versifican, lo hacen en décimas, sonetos, villancicos, loas, octavas y romances contribuyendo a la honda religiosidad que plasma el orden arquitectónico en grandiosas iglesias y magníficos conventos.

La poesia y la piedra se concretan, entonces, en mito de religiosidad rica y suntuosa. Es don Luis de Góngora, quien ha definido con toda precisión el ideal barroco:

Goza, goza, el color, la luz, el oro...

Aureos y polícromos son los altares y áureas $e$ intrincadas son las poesías. Toda emoción religiosa se exterioriza en oro y adorno para hacerse más ostensible en el xvirr. La poesia, aún abundosa es cada vez de menor calidad. Sin embargo, en este siglo, como una paradoja, el sentimiento religioso brillantemente proyectado hacia fuera, se recoge $y$ se hace emoción intima en la poesía del padre Luis Felipe Neri de Alfaro, sacerdote criollo de magras y tortuosas carnes, cuyas penitencias y virtudes lo conducen a la santidad; hacedor de poesías que poseen un delicioso sentimiento cristiano que se refleja en stu hermosísimo soneto Pasto y Pastor... joya encantadora de la poesía mexicana, soneto que revela verdaderas habilidades de poeta y que no desdeñaría firmar un clásico.

Al llegar al elegante zócalo del neoclasicismo en que toda emoción se intelectualiza y razona en una Academia, la poesia religiosa es casi un mero recuerdo en relación a su auge anterior.

Nació el padre Luis Felipe Neri de Alfaro en la ciudad de México, el 25 de agosto de 1709. El ambiente de su niñez fué de piedad y devoción. En el se le enseñó el amor a la pasión dolorosa del Cristo.

Adolescente, principió a estudiar Teologia y Filosofía en el Real y Pontificio Seminario; allí empezó a conocer místicos y ascetas, cuyas enseñanzas y vidas más tarde imitaría.

En 1729 le tenemos graduado bachiller en Teología y siguiendo la carrera sacerdotal. Abandonó entonces, la ciudad de México y se fué a la villa de San Miguel el Grande, donde estaba la Congregación del Ora- 
torio, con su gran "fama de observancia y literatura", acordes a su disposición, siendo recibido en el 26 de mayo de 1730 .

"Aquí fué donde conociéndose llamado par Dios con más fuertes impulsos a la sublime dignidad del sacerdote, comenzó a prepararse para este ministerio, que comprende una multitud de obligaciones esenciales y muy difíciles de cumplir bien. Conocia que a más de las virtudes era necesaria la ciencia, porque un eclesiástico ignorante hace mucho daño a la Iglesia y a sí mismo, por eso dice el IV Concilio de Toledo que los sacerdotes deben evitar por todos modos la ignorancia que es madre fecunda de todos los errores". " Tan aguda observación del padre Díaz de Gamarra, la evitó el padre Alfaro. Las afirmaciones de sus contemporáneos dicen de su saber teológico que se corrobora en su sencilla novena: A la Flor más hermosa y salutifera de los Campos... destinada a sus feligreses cultos e ignaros. En ella aparecen en citas los libros por él conocidos y que dan idea de la amplia cultura eclesiástica que poseía. Ahí están los profetas Isaías y Jeremías; el Apocalipsis de San Juan, Salomón, los libros del Antiguo Testamento: El Eclesiastés, El Exodo; San Agustín; menciona también al famoso predicador medieval San Bernardo, a los escritos de Santa Teresa de Jesús, a los del excelso San Juan de la Cruz y varias veces al naturalista Plinio - no olvidemos que su siglo es enciclopedista-, y otros muchos autores que sería demasiado farragoso citar.

Alude asimismo en esta novena a la Venerable Sor María de Jesús (1602-1655), conocida comúnmente como Sor María de Agreda por ser este lugar de Castilla la Vieja el de su nacimiento. De todos los escrito-

1 El Sacerdate Fiel y Según el Corazón de Dios. Elogio Fúnebre que en las magnificas exequias celebradas en dia 22 de abril de 1776 en el Santuario de Jesús Nazaneno de Atoronilco a su patrón y fundador el $P$. Luts Felipe Neri de Alfaro dijo el Padre Doctor $D$. Juan Benito Diaz de Gamarra y Dábalos. Reimpresa con las licencias necesarias. Querétaro, 1904. La primera impresión de este Elogio, se hizo en la Biblioteca del Lic. Don José de Jaúregui, calle de San Bernardo. Año de 1776.

El padre Dlaz de Gamarra, nacido en Zamora en 1745 perteneció también a la Congregación del Oratorio y fué contemporáneo del padre Alfaro. Representa en so siglo uno de los más altos valores filosóficos. A su regreso de Europa donde conoce las modernas ideas de esta ciencia, defiende e impone en la cátedra la filosofia de Descartes en oposición a la anquilosada escolástica. Escribe entre otras obras importantes: Elementa Recentiores Philosophiae, Errores del Entendimiento humano, ésta última nuevamente impresa y prologada por don Federico Gomez de Orozco. Orador elocuente, pronuncia el sermón antes citado, sermón que ilustra detalladamente sobre la vida y penitencia admirable del padre Alfaro. Lz intenea labor renovadora emprendida por Gamarra se interrumpió con su prematura muerte el $1^{\circ}$ de noviembre de 1783 . 
res misticos es quizá, Sor María de Jesús, la que mayor influencia ejerció en su espiritu y en sus penitencias; pues muchas de las mortificaciones que se impuso Alfaro, parecen inspirarse en las llevadas a cabo por la Venerable Sor María, que gozó durante su vida, y aún después de su muerte, de gran fama de santidad "no sólo en estos Reynos, sino también por otros muy distantes" 2 al decir de su biógrafo fray Joseph Ximenez Samaniego.

Una vez ya ordenado sacerdote fué a radicarse al Santuario de Atotonilco, que se construyó debido a su entusiasmo y que puso bajo la advocación de Jesús Nazareno.

En la anteriormente citada novena, el padre Alfaro hace detalladas consideraciones acerca del por qué de la construcción del Santuario, y también en limpia y agradable prosa dibuja el paisaje donde se asienta la Santa Casa de Ejercicios, paisaje que siente y describe en función de Dios :

"Fué Atotonilco en sus principios como un páramo, o desierto, que sólo espinas producía, pues no solamente brotó materiales, por la espesura de nopales, mezquites, güisaches, cardos y otras plantas espinosas, que brota eriasa la tierra sin cultivo; sino en lo moral, por los muchos abrojos y espinas de pecados, que después ahi se cometian; porque al mismo tiempo, que la tierra con espinas producia (como hoy se advierten) mucha variedad de flores exquisitas, por fecundarla multitud de ojos de agua; las calientes y medicinales, que hacían el sitio más apetecible. De aquí nacia, que como los Hebreos desconocidos buscaban lugares frondosos en las soledades para ejecutar con más libertad sus idolatrias, torpezas y abominaciones; del mismo modo este paraje, no solamente fué teatro de Idolatrías de indios bárbaros, en tiempo que lo poseía la gentilidad, como aún hoy lo muestran muchos vestigios, más después en poder ya de los cristianos, fué lugar de desórdenes y sensualidades, porque en pretexto de baños tan saludables, eran los concursos, las músicas, convites, juegos y demás pecados, que de estas juntas se siguen muchos y desordenados. Si el pueblo idólatra se compara al ladrón, que entre las espesuras de un desierto, asecha al pasajero, para robarlo; no sólo podemos llamar desierto a este sitio,

2 Mystica Ciudad de Dios ... por Sor María de Jesás. Primera parte año de 1698. Con licencia. En Sevilla: por Juan Francisco de Blas, Impresor Mayor de dicha Ciudad, p. 5. 
por haber sido antes madriguera de muchos ladrones, que libraban su seguridad en la espesura de sus silvestres plantas de donde salian a hacer robos y quitar carniceros lobos muchas vidas como lo han testificado las osamentas que se han sacado de varios cuerpos, que entre sus nopales sepultaban, sino aún después por muchos años fué el recurso de los ladrones de la castidad, que aquí asechaban a muchas personas, que entre las saludables aguas buscaban la salud del cuerpo, solicitando que perdiesen la mejor vida, que era la del alma; pero nuestro Soberano Dios Misericordioso para que sobreabundase la gracia, donde abundó la culpa, ha hecho de este desierto un ameno Paraíso, que (aunque asi pudiera llamarse por sus medicinales fuentes pues numera hasta veinte y siete ojos de agua, los cuatro calientes, por sus flores, árboles, vides, yerbas, y contrayerbas, situación y otras circunstancias) lo es más por el Nazareno Florido, como Flor de aquel Campo, o Lirio de aquel Valle, o por la Rosa de Jericó, y cándida Azucena María Santísima, con el título de Refugio, que allí con sus fragancias suaves, en un Santuario que infunde devoción y mueve a ternura, han atraido a muchas almas, pues acuden varias personas de diversas partes del reino a ejercicios, confesiones y comuniones ..." 8

En su bello libro San Miguel de Allende, Francisco de la Maza hace la descripción arquitectónica y plástica del Santuario: "Empezó a construirse el año de gracia de 1746, terminándose el templo principal en 1748. Posteriormente a estas fechas se le agregaron algunas capillas todas del siglo xvin, y en el siglo pasado se construyeron diversos patios y departamentos, hasta la fecha presente, en que quedó definitivamente levantado como Casa de Ejercicios ... Es el Santuario de Atotonilco una verdadera colección de capillas de diversos tamaños, que se agrupan y desembocan en la iglesia principal. No siguen un tipo fijo de arquitectura, sino las inspiraciones del momento y las varias direcciones, ya del padre Alfaro, ya de los maestros albañiles, hacen un conjunto multiforme, siguiendo el estilo que se ha dado en llamar popular. La fachada principal, sencillísima, se continúa por la Capilla del Santo Sepulcro, formando con la torre y cúpula de ésta, un largo plano de gran atracción plástica. Entre otros puntos de vista, sorprenden las cúpulas de muy originales formas, como de corona real, de tiara, etc., y las torres". "

3 A la hermosa y salutifera Flor de los Campos... Reimpresa en México en la Nueva Imprenta Madrileña de los Hetederos del Lic. D. Jaseph de Jaúregui; calle de San Bernardo. Año de 1785.

4 Publicación del Instituto de Investigaciones Estéticas. Mérico. 1939. Păg. 210. 
Cada año, en el santuario de Atotonilco, el padre Alfaro realizaba seis tandas de ejercicios y dias de retiro, a ellos asistian "cincuenta o setenta pobres" a los cuales humildemente atendía y servía.

$Y$ ahí también, practicó duras disciplinas en su anhelo de llegar a comunicarse con su amadísimo Jesús. El padre Alfaro que no era un místico, y sí un asceta, hubo de ejercitarse como tal, en los sacrificios inherentes a la perfección cristiana.

En la mística hay contemplación, éxtasis, visiones y revelaciones y es Dios mismo quien escoge al alma para unirse a ella e iluminarla con su amor. San Juan de la Cruz en su Noche Escura del Alma, explica mejor que cualquier tratado, la actitud del alma y lo que se entiende por teologia mística : "contemplación infusa o mystica-teologia, en que de secreto enseña Dios al alma, y le instruye en perfección de amor, sin ella hacer nada más que atender amorosamente a Dios, oirle y recibir su luz, sin entender cómo es esta contemplación infusa. Por cuanto es sabiduría de Dios amorosa, la cual hace particulares efectos en el alma : porque la dispone purgándola, y iluminándola para la unión con Dios: donde la misma sabiduría amorosa, que purga los espíritus bienaventurados, ilustrándolos, es la que aqui purga al alma, y la ilumina". "

El alma, que en la mistica es pasiva, se torna activísima en la ascética, pues debe liberarse del pecado por medio de la penitencia y de la mortificación, "vía purgativa"; debe intensificar la virtud con la oración y la imitación del Salvador, "vía iluminativa"; para llegar con ayuda de la gracia divina a unirse a Dios por la "vía unitiva".

La mortificación y laceria a que el padre Alfaro sometió su cuerpo fueron tan intensas, que no podemos dejar de transcribir lo visto $y$ atestiguado por el aludido doctor Díaz de Gamarra, en el Elogio Fúnebre que pronunció a la muerte del fundador de la Casa de Ejercicios.

El año de 1741 el padre Alfaro escribió : "quitaré el colchón y delicadeza de la cama y no se me pasará día sin alguna mortificación en el comer y en el beber". "En efecto -dice Gamarra- no usó por muchos años sino una zalea y dos frazadas bien ligeras. Su comida fué siempre tan escasa que apenas si podía entretener el hambre. Cuando gustaba de algún manjar, lo dejaba luego, o lo mezclaba al descuido, por no ser notado, un poco de acíbar que siempre traía en la bolsa. Los cilicios que cargó toda su vida eran

5 Obras Espirituales. . . por el extático y sublime docror mystico el Beato Padre San Juan de la Cruz. Impresion duodecima. Con licencia. En Sevilla, por Francisco Leefdael, en la Ballestilla. 1703 años. p. 225. 
tantos que apenas le dejaban libres las coyunturas del cuerpo ... ¡ Cuántas veces en estos últimos años, que tenía yo la fortuna de ayudarle a vestir los paramentos sagrados para celebrar el tremendo sacrificio no podía meterle las mangas de la alba por estar todo el brazo armado !. . . Los viernes que pasaba comiendo pan de lágrimas, se vestía un jubón que sólo verlo pone horror: éste le cogía toda la espalda, todo el pecho y la caja del cuerpo, con unas puntas tan penetrantes, que aún los dedos se lastiman al tocarlo... Los Viernes Santos, en que la Iglesia Nuestra Madre pone a la vista la lamentable catástrofe de la muerte de nuestro amabilísimo Redentor Jesús Nazareno, a más del pan de lágrimas y un poco de ceniza, que era su alimento a más del jubón ya dicho, se ponia en los pies unas plantillas de hoja lata tan ásperas que parecía imposible diese un paso; en las rodillas se ponía unas láminas cóncavas del mismo artificio, y crucificaba de modo su cuerpo, que apenas hallarías en él parte sano. En todos los dias de ejercicios y retiro se armaba del jubón, como buen soldado de Cristo, y duplicaba las penitencias, y todo esto lo hacia con tal disimulo, dándole al cuerpo todos sus naturales movimientos a expensas de inmensos dolores que sufria, que no diriais que pudiese estar atormentado, ni aún de la más ligera incomodidad ... en los Viernes Santos, en aquella devotísima procesión, que dispuso su ardiente celo y amor a su Nazareno Jesús lo visteis con una soga al cuello, con una corona de penetrantes espinas, que le introducian por la frente y bañaban su rostro de sangre, cargando un pesado madero, ${ }^{6}$ por dar con él las tres caidas en memoria de las que por nosotros dió Jesús en la calle de la Amargura, y para esto pagaba a un hombre robusto, que sin piedad lo estiraba de los pies, para dar de este modo un fuerte golpe en tierra, con el que se le hincaban más las espinas de la corona... Era tanto lo que padecía el cuerpo y el espíritu de Luis en esta dolorosa procesión, que explicándose muchos años después con una alma, que le mereció confianza la dijo: que en ese día moría tres veces al dar las caidas, según que los dolores del cuerpo, y las penas que sentía en el alma al contemplar caído a Jesús." 7

De otras muchas penitencias habla el doctor Gamarra: su sueño, más que descanso, parecia vigilia, y durante muchos años tuvo por grata compañia un esqueleto; también durante muchos años por las noches dejaba su lecho, para irse a orar ante la amada imagen de Jesús Nazareno y yacer en un ataúd que se hallaba bajo el altar, donde meditaba y se preparaba

6 La cruz del padre Alfaro se conserva aun en Ia Iglesia del Oratorio.

7 El Sacerdote Fiel ... pp. 13 y 14. 
a bien morir, con tan grande constancia, que gastó tres ataúdes, por lo cual decia con gracia "ya se me han podrido tres chalupas". Además de estas penitencias sobrellevaba con alegría sus enfermedades.

Las funciones sacerdotales las cumplía con gran celo e inteligencia; cuando confesaba "dirigía a las almas con aquella sabiduría que dispone de todas las cosas con tanta suavidad como fuerza"; por esto, malévolos interpretadores calificaron a Alfaro de "confesor ancho"; pero ni a Santa Teresa gustaron nunca confesores duros y secos. En la suavidad y tacto -modo sublime de atraer a las almas a verdadera contrición-, el padre Alfaro seguía a San Juan de la Cruz que con admirable penetración psicológica norma la conducta de los regidores de almas, sobre todo de aquelias que sufren escrúpulos, pues evitándoles torturas innecesarias obtendrán mayor provecho que si "hacen a las dichas almas revolver sus vidas y hacer muchas confesiones generales y crucificarlas de nuevo; no entiendo que aquel por ventura no es tiempo de eso ni de esotro, sino dejarlas así en la purgación que Dios las tiene, consolándolas y animándolas a que quieran aquello hasta que Dios quiera; que hasta entonces por más que hagan $y$ ellos digan no hay remedio". $s$

Desconocía la envidia, practicaba el amor al prójimo y la caridad. Fundó, además de la Casa de Ejercicios de Atotonilco, la Santa Escuela de San Miguel el Grande, la de Guanajuato y la de León. Y cumplidos de modo tan perfecto sus deberes murió "con una corona de espinas y una soga al cuello", el viernes 22 de marzo del afio 1776.

En el padre Alfaro nos interesa, además, de su admirable ascetismo, su producción poética, pues a pesar de los cilicios y funciones sacerdotales que lo absorbian, alcanzaba a escribir las novenas $y$ oraciones con las cuales sus feligreses se encomendaban a Jestus y a la Virgen, oraciones que unas veces estaban en prosa y otras en verso. Con ellas explicaba los conceptos sacros, los atributos de santos y apóstoles en forma poética con las ciaras comparaciones de lo visto cotidianamente para su mejor comprensión, como

8 Citado en La Vide Eupafola en la Edad de Oro. A. Valbuena y Prat. Barcelona. 1943. Pág. 86. 
lo hicieran San Juan de la Cruz, Santa Teresa y fray Luis de León, quien usa términos tan populares como "jabonadas", locución que un exquisito poeta de nuestros dias, García Lorca, repite:

En la lucha daba saltos jabonados de delfin...

De este modo el padre Alfaro, al referirse a San Juan a quien llama el "Benjamín de los Apóstoles" y el más delicado receptor del amor de Dios dice llanamente: "purísimo huerto florido de virtudes de la militante Iglesia en cuyo amoroso pecho, como en un vistoso jardín se mira la cándida azucena de tu pureza, la nacarada rosa de tu caridad, la violeta morada de tu compasión; pues como una abejita tierna en el florido paraíso de la más sagrada escuela de Jesús, chupaste la miel de las flores de su pasión santa, y de los dolores de su tiernísima madre, sintiendo como propios sus tormentos y penas ..."Y en otra ocasión, en que habla del comportamiento que en la iglesia debe observarse, lo hace tan sencilla y encantadoramente que hasta el diablo se poetiza en un gracioso diminutivo: "En rezando, en leyendo sea con atención y devoción, porque regularmente muere sin habla, quien habla atropelladamente las divinas alabanzas y el diablo Tintillo te lo va apuntando todo."

Sus poesías quedaron en novenas y en las paredes y bóvedas del Santuario de Atotonilco, con las pinturas que ìlustran sobre el infierno que espera a los pecadores, pinturas "en las que la prodigiosa imaginación mística de Alfaro supo desarrollarse en multitud de escenas llenas de movimiento y colorido, con gran interés folklórico y psicológico. Esta gigantesca y única obra de pintura popular de altos vuelos, formada como por inmensos y fantásticos "retablos" o exvotos de piedra, tiene por asuntos principales, que los anónimos artistas ejecutaron bajo la dirección de Alfaro los de la vida, pasión y muerte de Jesucristo siendo tan maravillosa e inagotable la maginación directora de esta obra pictórica, que en las escenas dichas, a las cuales no se les escatima toda clase de personajes humanos y divinos, se suceden innumerables letreros, sonetos y poemas místicos, entrelazados con guirnaldas de hojas de flores y frutos en que es agotada la gama más rica y satisfecha la curiosidad más exigente"."

Algunas de sus poesias tienen, al igual que las pinturas, el encanto $y$ frescor populares que lo distinguen de los hinchados poetas de su época,

9 Francisco de la Maza. San Miguel Allende. Págs. 210-211. 
y lo acercan más a nuestra sensibilidad. Algunas otras siguen, como es natural, la ampulosa corriente erudita y son, acaso, las menos sentidas.

Procuraremos analizar, en este pequeño estudio, su poesia y las influencias que en ella se advierten.

Al final del trabajo consignamos las poesías escritas en los muros del Santuario, transcribimos algunas de las dispersas en sus novenas y damos noticia de las varias impresiones de éstas mismas, que en su obra. $L a$ Imprenta en México, recoge el erudito don José Toribio Medina, y dan a conocer la gran difusión que tuvieron dichas novenas.

Agradecemos al historiador Francisco de la Maza su gentileza al proporcionarnos las poesías completas que copió de los muros del Santuario de Atotonilco y algunos impresos del padre Alfaro. Agradecemos, asimismo, al doctor Alfonso Méndez Plancarte, sus consejos para este estudio.

En la producción poemática del padre Luis Felipe Neri de Alfaro se distinguen dos claros matices: el erudito y el que podría llamarse popular.

Sus poemas en octavas reales: Las Tentaciones de Cristo, Cristo en la Cruz, La Magdalena unge a Jesús, La Multiplicación de los Panes y Promesas de lá Eucaristía y Los Milagros del Agua y del Vino, revelan franca tendencia gongorista; tendencia que durante el siglo xvIr y hasta mediados del xIx sigue irmperando en México, no obstante la gran renovación intelectual en las ideas filosóficas y en las letras - reacción contra Góngora. $Y$ aún como en el xVII, las realidades se concretan en símbolos míticos. En las poesias ya citadas, las características de la escuela culterana son una constante. Reaparece el forzado hipérbaton:

Moisés, primero, el Salvadot divino, el trigo de Belén amante aplica...

el nombre trivial de las cosas, el trigo, por ejemplo, se elude con belleza: de oro trillado el campo ameno llena ...

y los ojos son claveles: 
In undados en llanto sus claveles, se postra reverente su decoro. dando a Ios pies del Salvador fieles el rico Ofir de sus madejas de oro...

En el elemento mitológico, Cristo se cornpara con Hércules:

Ya se acerca el dragón al sacro Alcides

que adoran los olímpicos penates,

$\checkmark$ annque teme invadir béroe tan fuerte.

ain embargo le dice de esta enerte...

y esta otra comparación :

Tú eres la litz del divino Orfeo

que mueve ya $a$ los troncos y a las fieras.

que ya deshechas en tu canto, veo

las leyes del infierno más aeveras...

Estas bellas octavas recuerdan aún más, por el color y la estructura, a Góngora :

Ya la vid verdadera fructifica

el aéctar de sus ramos exprimido,

en la feliz Caná donde alambica

dulces glorias el pámpano florido.

Purpúteo vino es ya cuanto rubrica,

a cuyo honor se mira reducido

el líquido elemento cuya forma

en glorias de María se transforma.

E1 cándido licor gustoso admite

el rosado matiz y los cristales

aquel sabor reciben, que compite

las dulces ambrosias celestiales...

Afirma Alfonso Reyes, que "Góngora en las formas heroicas buscaba exquisiteces de expresión tan remontadas que llegaba a construir nuevas palabras castellanizando los términos latinos". ${ }^{10}$ Nuestro padre Alfaro imita este recurso culterano en las "formas heroicas", las octavas reales, españolizando también palabras griegas y latinas:

cuyas hojes son Fármaco dichoso...

10 Alfoneo Reyes. Capitulos de Literatura Española. Segunda serie. México. México, 1945. Pág. 182 . 
y en esta otra :

comió toda la turba y los fragmentos

redundaron en cándidos confinos...

y también en su poema Los Milagros del Agua y del Vino:

Dime ya tú Deipara Divina,

los milagros. que tu Jesús precioso...

Ahora bien, no advertimos en los sonetos de Alfaro la presencia de Góngora. Sencillos pero sin pobreza de lenguaje, con adjetivos y sustantivos armoniosamente dispuestos, como hechos por un hábil versificador, prevalece en ellos el sentimiento que los hace muy delicados:

Si le quieres buscar, Madte querida,

en mi pecho le tengo sepultado.

que aunque grosetamente le be tratado

ya me inundo de llanto en la avenida...

El mejor de sus sonetos, y en general de su poesía, es sin duda aquel hermosísimo, escrito en los muros de la Casa de Ejercicios de Atotonilco, que dice :

1Pasto y Pastor! IQué taro of recimiento

el cielo te presenta, ob peregrino I

¿Pasto y Pastor! dichoso tu destino

si sabes apreciar tal llamamiento.

Pasto y Pastor a un tiempo: iqué portentol

Divino el Pasto, ai el Pastor divino.

Con tal Pastor, ¿quién perder el camino?

Con Pasto tal, ¿quién perderá el aliento?

Mi Pasto $y$ mi Pastor rois, Jesús mío:

que asi vuestra palabra me lo advierte.

reprendiendo mi loco desvario,

y anunciándome en todo feliz suerte.

Sois mi Pastor: no temo ya extravio.

Soil mi Pasto: no temo ya la muerte.

Este soneto, la más bella composición del padre Alfaro, difiere por su altísima calidad y perfección del tono general de su poetia; calidad 
misma que podría hacer dudar de que fuese suya; sin embargo, creemos que el soneto sí le pertenece, pues siempre una idea, o el modo especial de adjetivar, o una simple palabra, o un vívido o tenue color, se reiteran en el curso de la producción de un escritor haciendo posible reconocer su firma. ¿Quién no señalaría de inmediato las maravillosas tercias de adjetivos de don Ramón Maria del Valle Inclán, o el color predilecto de don Luis de Góngora o de fray Luis de León?

En su precioso libro Leyendo a ..., José Moreno Villa afirma: "lo que persigo con esta disección es conseguir, destacar las palabras o palabra que dibuja el carácter o la psique del autor; porque tengo la visión previa de que en cada poeta se repiten obstinadamente ciertos vocablos que son como su germen y a la vez su emblema o símbolo". 11 Por tanto, si tomamos en consideración el método anteriormente expuesto, encontraremos las palabras que más usa el padre Alfaro y que nos demostrarán que sí es él, autor del soneto.

En varias de las composiciones del poético capellán de Atotonilco. el sustantivo portento y el adjetivo portentoso reaparecen con frecuencia, así en las Tentaciones de Cristo:

Si eres hijo de Dios haz un portento...

y también en la poesía Cristo en la Cruz:

IOh árbol del Paraíso portentoso...

y más claramente en La Multiplicación de los Panes y Promeso de la Eucaristia :
Vuestro maná. no preservó el extremo término de la vida; este suspende la corrupción, que pan de entendimiento de los portentos admiró el portento.

$\mathbf{Y}$ ante la inefable sintesis de Cristo : Pasto y Pastor ... se vale de la voz sustantiva que más le agrada: Iqué portento! para decirnos la admiración que en su ánimo provoca tan sublime concepto: si Cristo es nuestro Pasto, por ese solo hecho el hombre alcanza la divinidad. Con cuánta razón se maravilla Alfaro, y cuán preciso es el sustantivo que aplica. Ade-

11 Jone Moreno Villa. Leyendo a . . . Colegio de Mixico, 1946. 
más, la idea desarrollada en los versos anteriores de que quien dignamente recibe la Eucaristía no parece, coincide con la comparación tácita que hace en la última línea del tan citado soneto:

Sois mi Pasto: no temo ya la muerte.

El soneto es expresión lírica de su esperanza y de su amor a Jesús Sacramentado; amor que lo lleva a realizar tremendas penitencias para recibir con unción el Pasto divino. ${ }^{12}$

Por lo anteriormente dicho y por las poesias antes consignadas que denotan al padre Alfaro como un poeta de calidad, creemos que el soneto debe incluirse en su producción.

Es posible que el antecedente directo del soneto esté en la hermosísima alegoría De la Vida del Cielo, "la más mística de las realizaciones líricas" de fray Luis de León, en la que figura un verso Pastor y Pasto él solo y sucrte buena...

Ya dentro de la montaña

del alto bien las guía: ya en la vena

del gozo fiel las baña,

y Ies da mesa llena.

Pastor y Pasto di solo y suerte buena... 1s

12 Un poeta contempotáneo, Miguel de Unamuno, dice lleno de angustia mística en su poesia Eucaristía que "es necesario sentir en carne propia como lo hizo Alfaro-, los dolores de Cristo" para "vivit muerte de vida" Y calmat el hambre de Dios $y$ de inmortalidad:

Sólo comerte nos apaga el ansia. pan de inmortalidad, carne divina.

Nuestro amor entrañado, amor hecho hambre,

iOh Cordero de Diost manjar Te quiere;

quiere saber sabor de tus redaños.

comer tu corazón y que su pulpa

como maná celestial se derrita

sobre el ardor de noestra lengua seca:

que no es gozar de Ti: es bacerte nuestro.

carne de nuestra carne, y tus dolores

pasar para vivir maerte de vida...

13 Fray Luis de León. Bíblioteca de Autores Españoles. Madrid. 1855. Tomo 57, píg. 6. 
Pero más que en la alegoria, el antecedente del soneto está en las explicaciones que fray Luis de León escribe acerca de cada una de las palabras del verso Pastor y pasto .... en el capitulo llamado Pastor de su obra Los Nombres de Cristo, capítulo en el cual, el padre agustino expone sus ideas políticas, elogia el paisaje - tema no esencial a su tiempo- $y$, no obstante, admirablemente descrito. Estas consideraciones con su obvio contenido son, a nuestro juicio, el manantial de donde proviene el soneto.

Fray Luis de León, que personifica a Marcelo, uno de los interlocutores de Los Nombres de Cristo, comenta el por qué del nombre Pastor que se atribuye a Jesús: "Llámase también Cristo Pastor. El mismo dice en San Juan: $-Y_{o}$ soy el buen pastor-. Y en la epístola a los hebreos dice San Pablo de Dios:- Que resucitó a Jesús, pastor grande de ovejas-. Y San Pedro dél mismo: Cuando apareciere el Príncipe de los pastores... yo apacentaré a mi rebaño y yo le haré que repose, dice Dios el Señor. A la oveja perdida buscaré a la absentada tornaré a su rebaño, ligaré a la quebrada y daré fuerza a la enferma, y a la gruesa y fuerte castigaré, paceréla en juicio". Nuestro padre Alfaro repite:

Con tal Pastor, ¿quién perderá el camino?

que asi vuentra palabra me lo advierte

reprendiendo mi loco desvarío...

Marcelo continúa su exposición y habla ahora del sentido simbólico del Pasto: " $y$ si con justa causa pone a Cristo, que es su Pastor en medio de las entrañas del hombre, para que, poderosos sobre ellas guíe sus opiniones, sus juicios, sus apetitos, $y$ deseos al bien, con que se alimente $y$ cobre siempre mayores fuerzas el alma, y se cumpla desta manera lo mismo que el Profeta dice: Que serán apacentados en todos los mejores pastos de su tierra propia; esto es, en aquello que es pura y propiamente suerte buena", 14 Discurso a la perfección comprendido por Alfaro cuando escribe :

Pasto y Pastor; 1qué caro of recimiento el cielo te presenta, ob peregrino!

14 Fray Lais de León desarrolla aqui más ampliamente su idea : a dulces pastos mueve... de su poesía De la Vida del Cielo escrita probablemente entre los años de 1576-1580. es decir, anterior al capítulo Pastor para el cual se fija la fecha de 1583 : y por lo tanto con mayor amplitud tratada. Luis da León Aubrey. F. X. Bell. Barcelona. p. 268. 


\section{Pasto y Paztor: dichoso tu deatino si sabes apreciar tal llamamiento...}

De la expresión: él solo, fray Luis de León dice "promete un solo Pastor, así para mostrar que Cristo puede con todo, como para enseñar que en él es siempre uno el que rige". Marcelo concluye su diálogo: "que es asi pastor, que es pasto también y que su apacentar es darse a si a sus ovejas... en el suelo las apacienta, y en el cielo será también su pastor, cuando allá las llevare, y en cuanto se revolvieren los siglos y en cuanto vivieren sus ovejas, que vivirán eternamente en él, él vivirá en ellas, comunicándoles su misma vida, hecho su pastor y su pasto". ${ }^{15}$ Aqui Marcelo calló, dice desde su cárcel en Valladolid fray Luis de León, pero plácenos imaginar que, en tanto de silencio se henchía el huerto de La Flecha, el teólogo saimantino terminaría en estupenda prosa y bello estilo uno de los diálogos comenzados allá, por una luminosa mañana del mes de junio -cabe el picaresco Tormes- y cuyas ideas, en primoroso verso recordará nuestro padre Alfaro:

Pasto y Pastor a un tiempo: I qué portento!

Divino el Pasto, ai el Pastor divino.

Sois mi Pastor: no temo ya extravio

Sois mi Pasto: no temo ya la muerte.

Y nada de extraordinario tiene que el señero fray Luis de León influyese en él de manera tan notoria, pues por su gran calidad artística y stu saber doctrinal fueron muy leidas $y$ divulgadas sus obras, en aquel entonces y aún hoy, el gusto por ellas permanece intacto; además el padre Alfaro sentía especial atractivo por esta clase de escritos ya que según sus biógrafos nunca "leyó novelas ni comedias".

Sus lecturas, además de las teológicas, debieron ser $L a$ Guia de Pecadores del formidable orador fray Luis de Granada; Las Obras espirituales de San Juan de la Cruz; las de Malón de Chaide, el discípulo de fray Luis de León, y el divino Cantar de los Cantares; libro en el cual casi todos los escritores místicos se han inspirado. Aquí en América, la monja Francisca

15 Fray Luis de León. Biblioteca de Autores Españoles. Madrid. 1855. Tomo 57. pág. 93. 
Josefa del Castillo (1671-1742) que vivió en Tunja, provincia del Reino de Nueva Granada, escribió un libro: Afectos Espirituales con grandes reminiscencias del Cantar de los Cantares; ella y San Juan de la Cruz afirma Picón Salas "encontraron en el poema bíblico el lenguaje en que podría simbolizarse su avidez y embeleso místico".

El padre Alfaro lo conoce bien y alguna vez lo memora en sus versos, pues si la Sulamita del Cantar... elogia al Esposo:

tu nombre es suave oloz bien derramado. y no hay olor que iguale a tus olores: por eso las doncellas te han amado, conociendo tus gracias y dulzores...

el alma del padre Alfaro, esposa de Cristo, le murmura:

Cual Flor del campo exhaluis tales fragancias $y$ olores, que al campo y a todas sus flores. en ellas aventajáis.

i $\mathrm{Y}$ cómo vibraria de cristiana emoción al leer los sonetos:

Pastor que con tus amorosas y ¿Qué tengo yo que mi amistad procuras? del siempre arrepentido y nunca del todo penitente frey Félix Lope de Vega y Carpio!

El padre Alfaro conocía sin duda los sonetos mencionados, pues toda poesía religiosa alcanzaba durante la Colonia rápida difusión. Recordemos que el bellísimo soneto mexicano que empieza: No me mueve mi Dios para quererte ... prontamente se difundió en todos los dominios hispánicos.

Lope, católico ferviente, incapaz de ponex en entredicho los dogmas de la fe, no tenía más regateos con el Señor para darse a él plenamente que los de su temperamento ardoroso; en estos sonetos muestra la indecisión del alma ante las instancias del Salvador:

iCuántas veces el angel me decía:

"Alma asbmate agora a la ventana:

vetás con cuánto amor llamar porfia".

iY cuantas hermosura sobetana,

"mañana le abriremos" respondia,

para lo mistno responder mañana! 
y las promesas que el alma arrepentida al fin otorga:

$$
\begin{aligned}
& \text { Vuelve los ojos a mi fé piadosos } \\
& \text { pues te confieso por mi amor y dueño } \\
& \text { y la palabta de seguitte empeño } \\
& \text { tus dulces silbos y tus pies hermosos... }
\end{aligned}
$$

En las siguientes líneas del padre Alfaro se percibe el precioso eco de los versos del Fénix y aun te supera en el deseo de una entrega total e inmediata, sin reticencias, abriéndole la puerta, no como Lope que deja pasar un día y otro día, sino al primer leve rumor y se obliga a seguir a Cristo, ya sea en su alegoría de Pastor o en la de Cordero:

Vos $\bar{y}$ yo, Jesís amante,

hemos amado a porfia:

yo buyo de vos cada día,

Vos me buscais cada instante.

Pero ya desde hoy constante

seguiros mi bien espero.

porque ya me considero

tan preso de vuestro amor

que si no os aeguí pastor.

os be de seguir cordero.

Pensamiento que reaparece en esta décima:

Ingrato $y$ desconocido

confieso, mi Dios, que fuí.

vos siempre mirsis por mi.

yo siempre de vos me olvido:

pero ya reconocido

mis ingratitudes lloro,

$y$ vuestro favor imploro

pare explear mi corazón

en sentir vuestra pasión,

que es donde está mi tesoro.

También en tierno y delicado soneto hallamos estos sentires lopescos, consonantes a su espíritu:

Duicisimo Jesús, Dios verdadero,

Nazareno, divino, hermosa Flor,

mi rey, mi dueño, padre y Redentor

a quien amo, en quien creo y en quien espero. 
Ya que asi me boscsis, me babtis de ballar. pues yo también os busco arrepentido. y espero que me habéis de perdonar.

Porque amor, $y$ dolor me traen rendido; y atí ya, dueño mío, no máo pecar: perdón, ioh mi Jests! ipendón os pido!

El verso que figura en el anterior soneto:

Ya que asi the buecsis the habtis de ballax...

resuena al delicado renglón de Gutierre đe Cetina en su célebre madrigal Ojos claros...

Ya que así me mirstis, mitadme al menos!...

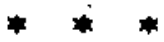

El padre Alfaro también conoció a Sor Maria de la Antigua, monja española del siglo XVIr, de abundante producción religiosa, pues escribió, según se dice, más de mil trescientos cuadernos de singular enjundia; entre ellos está la:

Cadena de oro, / evangélica red, / arrojada a la diestra / de los electos / y Escogidos / Que muestra el mas cierto, seguro, / breve camino para la salvación / eterma. Las Estaciones de la Dolorosa Passion y Muerte de Nro. Amantissimo Redemptor Jesus. ${ }^{16}$ que debe haber tenido gran difusión en la Colonia pues sólo don José Toribio Medina en su abra La Imprenta en México consigna nueve impresiones todas del siglo xvirI ${ }^{17}$ sin embargo, La Cadena de Oro ... debe haberse divulgado desde antes por medio de las impresiones españolas.

Esta Cadena de Oro... de la Madre Sor Maria la Antigua la utiliza el padre Alfaro en su novena que titula de la misma manera: Cadena de

16 Escritas por la V. M. Maria de la Antigua, Religiasa de N. M. Santa Clata / en el Convento / de Marchena. Repartidas por los dias de una Sema-na, para mas, comodidad divididoz / en tres Semanas. / (Filete). Reimpresa en México. en la Imprenta de la Bibliotheca Mexicana, enfronte de San Agustin. Año de 1755. José Totibio Medina. La Imprenta en Mexico. Tomo v, p. 226.

17 Joat Toribio Medina, tomo vi pp. 54, 97, 175, 211, 348, 376 y 582, Tomo v, p. 13. 
oro que asegura a los Escojidos, no dexandolos salir del camino de su salvacion y a los pecadores pone en el sendero de la virtud. Estaciones que practicaba la V. Maria la Antigua, en las que meditaba la Dolorosa Passion, y Muerte de Nuestro Amabilissimo Redentor Jesus Nasareno. Practicadas en Verso en los Exercicios que se hacen en el Santuario de su Magestad Sagrada en la Labor de Atotonilco. Por el P. Luis Fhelipe Neri de Alfaro su indigno Capellan. ${ }^{18}$

En el ofrecimiento de la Cadena de Oro el padre Alfaro explica por qué sigue a la Madre María :

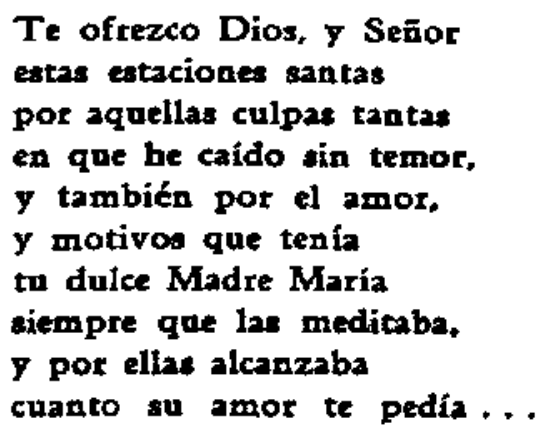

y también aclara en verso la significación de la Cadena:
Esta Cadena obligado
te consagro reverente.
de ella tenme fuertemente.
Y a todo nos ealabona,
nuestros pecados perdona,
7 has que vayamos a verte.

En la Cadena de Oro... todas las estaciones están versificadas con el objeto - dice Alfaro- de que no se olviden, y también "como son más cortas nadie dejará de rezarlas". ¿ Cómo no recordar, entonces, esta súplica deliciosa en su ritmo ingenuo de canción infantil?:

\footnotetext{
Que cuando bayas de juzgar

con tus iras justicieras,

no me quiexas, no me quieras.

no me quieras condenar.
}

18 Con licencia: Impresa en México en la Imprenta de el Real y más Antiguo Colegio de San Ildefonso año de 1776 . 
$Y$ en los versos que siguen escuchamos no a un poeta del $\mathrm{Xvnur}$, sino a un sencillo y encantador poeta, a lo Gil Vicente, que tanto se conduele de los sufrimientos del Sefior, que no acierta a decir nada:

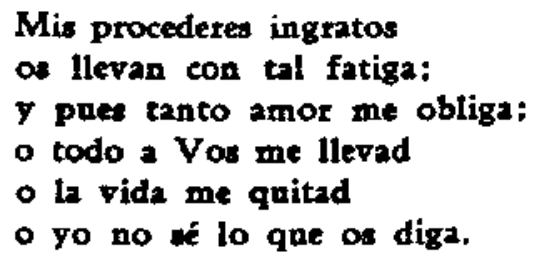

Y en esta bella estación del Descendimiento con una metáfora novedosa, el corazón se arroja por los ojos:

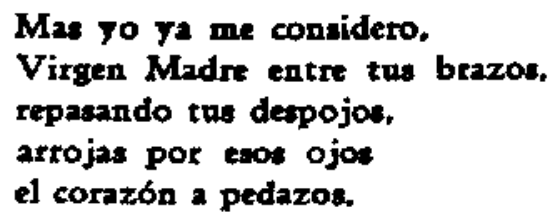

Toda la poesía de la Cadena de Oro ... es de factura sugestivamente popular, tierna y dulce, que tan interesante hace al padre Alfaro, pues símbolos y pesadas comparaciones se sintetizan en amoroso y sencillo lenguaje:

$$
\begin{aligned}
& \text { Para llotar mis atrojos, } \\
& \text { de la congojz oprimido, } \\
& \text { juzgas mi Jeats querido } \\
& \text { no we bastantes los ojos: } \\
& \text { al ver de Dios los enojos } \\
& \text { eata tu Madre llorosa, } \\
& \text { de tu pasión lastimosa, } \\
& \text { tan malogrado tesoro, } \\
& \text { hilo a bilo por cada poro } \\
& \text { corre to sangre pretiosa. }
\end{aligned}
$$$$
\text { *** }
$$

La más antigua poesía alude a las flores. Los griegos las sublimaron en minutos, y Ausonio, poeta latino, las compara con lo huidizo de la belleza y juventud femeninas, comparación brillantemente continuada por Góngora, Sor Juana Inés de la Cruz, Calderón y Francisco de Rioja, y en este último los perfiles humanos se desvanecen para dejar tan sólo un apasionante culto a la flor. 
Entre los escritores misticos, fray Diego de Estella compara también la hermosura con la fugacidad de una flor en sus Cien Meditaciones del Amor de Dios: "La hermosura de las criaturas pequeña es, transitoria, momentánea y perecedera, hoy es fresca como la flor del campo y mañana está marchita. La hermosura de la criatura falta y dexa de ser al mejor tiempo, pero la hermosura del Criador para siempre la persevera y está con él." 10

El siglo xvmr, el científico, toca el tema floral desde un ángulo más botánico que poético; pero Alfaro que es verdadero poeta, no es insensible al encanto de las flores, y las relaciona, naturalmente, con el Salvador, aunque en ocasiones, para no perder la tónica de su época, lo hace con su poquito de erudición.

Ya el viejo Arcipreste de Hita compara delicadamente a la Virgen con las flores, en su Cántica de Loores a Santa Maria:

\author{
Quiero seguir \\ a ti flor de las flores! \\ siempre decir \\ cantar de tus loores: \\ non me partix \\ de te servir. \\ imejor de las mejores!
}

El padre Alfaro también lo hace lindamente: "Toda flor os retratais en los Cantares, Azucena entre espinas, rosa en el plantel de Jericó, huerto cerrado en donde las flores abundan, y florido lecho con flores esmaltado. Tu Cabeza Sagrada al Carmelo, que de flores y rosas te corona, es comparada: tu purísimo Vientre a un montón de trigo, de lirios y azucenas cercado se asemeja, y aun enferma de amor pedis, que os regalen y sustenten con odoriferas flores".

$Y$ es también una bellísima alegoria la dedicatoria de la novena: $A$ la mas hermosa y salutifera Flor de los Campos, al mas peregrino oloroso lirio de los valles, a la Rosa más fragante de los jardines, al clowel más discipinado de los huertos el Santínimo Redentor de nuestras almas: Jesús Nazareno Señor de Aguascalientes que como maestro divino y florido hortelano del celestial paraiso, las enseña en nueve flores y nueve daliciosos caminos para el cielo..."

19 M. Menéndez Pelayo. Historia de las Ideas Estéticas en Espafia. Buenos Aiזะs. 1943. Tomo II. pág. 94. 
La metáfora: al clowel más disciplinado de los huertos... es encantadora por su ascendencia popular; disciplirado, llama el pueblo a la flor que posee dos tonos: uno más intenso y otro más débil y que aplica, en especial, al clavel. Los lectores de la novena comprenderian de inmediato lo que el padre Alfaro queria hacerles entender: "Estos Flos (caryophyllus), que es lo mismo que la flor del clavel como si fué encarnado en el virginal vientre de su madre hermosa, fué también clavel blanco con la vestidura que le puso Herodes; con los azotes en el patio de Pilatos; morado con las bofetadas y golpes en Casa de Anás; rojo de la purpúrea sangre que le hizo verter la corona de espinas ... y como el clavel del campo que esparce suavisimas fragancias para que corriendo tras ellas, le sigan las almas que deseen imitarle ...."

En esta misma novena el padre Alfaro habla de las diferentes flores con las cuales se designa al Señor; por ejemplo de las Flores de Cordero, describe, con la minuciosidad de un botánico el sitio donde crecen, sus propiedades y su significación: "Las flores de Cordero, según Polo, llaman los naturalistas a unas flores blancas y purpúreas que producen unos átboles que nacen cerca de los rios y cristalinas aguas: tienen dichas flores no solamente la propiedad admirable de ser contravenenos $y$ otras cosas nocivas, sino que tienen especial proporción con la virtud de la castidad : 20 razón porque se llamaron flores del cordero".

Del lirio y de la azucena explica bellamente: "Este vocablo lirio no sólo significa la azucena olorosa y cándida, sino también el lirio fragante, llamado comúnmente el lirio cárdeno o morado, otros lo conocen por el iris de las flores, o ya porque en sus encarnadas hojas imita a aquel arco celeste, - ya por ostentar según especies y tiempos, los varios coloridos de blanco, azul, verde, morado y amarillo. De cualquier modo que sea es símbolo de Nuestro Nazareno hermoso, que no solamente es azucena purisima aunque

20 La planta contratia a la castidad sería la borraja a la que alude un antiguo romance expabol :

Hay una hierba en el campo

que la llaman la borkaja:

la mujer que la pisare

luego se siente preñada.

Esta piós doña Enxendra.

por in an desdichn mala... 
con el cerco de espinas que coronan su sagrada cabeza, sino también lirio cárdeno, y el iris más vistoso, que causó paces entre Dios y los hombres"; explicación que termina con esta coplilla que nos emociona por su frescura popular :

$$
\begin{aligned}
& \text { Porque las flores terrenas } \\
& \text { no roben ya mis amores, } \\
& \text { sigo tal lirio entre penas, } \\
& \text { que de espinas bace flores, } \\
& \text { y de espinar azucenas. }
\end{aligned}
$$

La flor de jacinto representa "Ios diferentes misterios de la pasión" todo el decir acerca de esta flor se resume con enorme ternura en esta quintilla, por demás preciosa:

$$
\begin{aligned}
& \text { Ya de tus tiemas caricias, } \\
& \text { mi Jesus y de tu amor. } \\
& \text { me da el Jacinto noticias; } \\
& \text { más lay que caras. Señor. } \\
& \text { te cuetun eatas deliciasl }
\end{aligned}
$$

Las comparaciones del Salvador con las flores son muy lindas y delicadas, pero la más admirable es la que hace con el Narciso. Sabidor como ya hemos visto de temas mitológicos - muestras de erudición al estilo de su época-, toma el pagano mito de Narciso y estupendamente lo cristianiza en la Canción y Gozos que se cantan en su santuario a la mas hermosa $y$ saludable Flor de los Campos... , canción que figura al final de la citada novena, y que tiende a lo popular, hecha según se dice, para que la entonen sencillos labios de visitantes al Santuario de Atotonilco; en esta Canción todas las flores aludidas en la novena, aparecen con un encantador estribillo.

La exquisita jerónima, Sor Juana Inés de la Cruz, en el siglo anterior, habia recordado con bellísimo simil este tema en su Romance del Divino Narciso:

de ver el teflejo hermoso

de su esplendor peregrino,

viendo en el Hombre an imagen

* enamoró de aí mismo... 
El padre Alfaro, cuando al viejo mito alude, en unas cuantas líneas dice su pensamiento; el espejo de agua clara e inmóvil, por lo mismo estéril, en el cual Narciso deleitosamente se contempla, es ahora sangre roja y "corriente" --sugerencia de todo un sentido simbólico de fecundidad- y al inclinar el Salvador la cabeza y mirar el reflejo de su rostro lacerado por el infinito amor al Hombre, termina enamorándose, no de su imagen como en el lindo romance de Sor Juana, sino de su propio y amoroso sacrificio:

\author{
Sois Narciso en la belleza, \\ que os mirarkis en la fuente \\ de vnestra sangre corriente. \\ cuando inclináia la cabeza: \\ fuentea del Salvador \\ las que vnestro amor previno. \\ Sois Nazareno Divino \\ la más aludable Flor.
}

No hay en la poesía del padre Alfaro, hondos probiemas teológicos a filosóficos, ni graves asuntos politicos como en el combativo fray Luis de León ; sino solamente la deliciosa divulgación de enseñanzas, dogmas y prácticas de vida cristiana, expresadas las más veces, con los términos usuales de una conversación ordinaria, por ejemplo esta diáfana y bonita octava:

Dos coronas te of recen dos señores, zrira, alma, con cuidado, a cual te inclinas; si a la que el mundo ofrece que es de flores, o a la que Cristo of rece que ea de espinas: $1 a$ de flores rematz en ainsabores, la de enpinas en glorias peregrinas: escoge puez lo de mayor nobleza, que es la que carga Cristo en su cabeza.

Y también en sencillos términos se dirige a San Pedro:

hax que yo renunciando a lo mundano, quede aberelto de toda culpa o vicio, 7 que en la gloria que se noe prepara no nos den con la puertas ea la cara. 
De su estilo podría decirse que es a veces descuidado; pero recordedemos que el maestro Luis de León era prolijo y "desde el siglo xvr acá han hablado los críticos del 'tosco desaliño' de sus versos mas él triunfa generalmente con su intrepidez sencilla". ${ }^{21}$ Así también al padre Alfaro la sencillez cautivadora lo salva de ser un mediocre y frío poeta del XVIII, pues sus versos con ripios muchos de ellos y con defectos, se recordarán por la ternura y el sentimiento de que están henchidos:

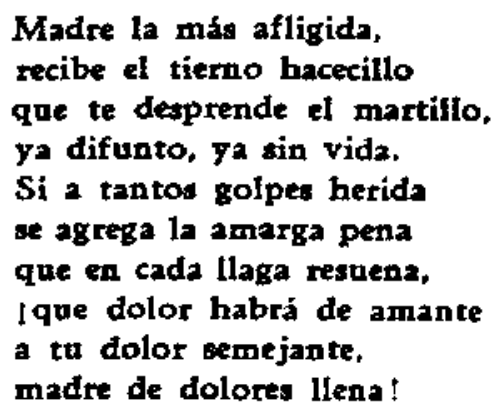

Alegorías, metáforas y antítesis populares lo acercan a la verdadera raíz hispánica: junto y tras de lo letrado el "román paladino"; el poeta español sólo es auténtico cuando se funde con el pueblo, hasta el mismo Góngora, cima de toda exquisitez, así lo comprendió. En su. Polifemo - hace notar Alfonso Reyes-, trae Góngora un pleonasmo tomado del habla de su pueblo cordobés; y en ese mismo poema "aparecía una metáfora que el crítico Pedro de Valencia le hizo ver que semejante juego de palabras y alusión tan casera eran impropias del estilo heroico de su poema" ${ }^{22}$ y en las poesías de Góngora quedaron, por tanto, las alusiones a la panadera, a la tuerta, a los dulces, bailes y en general de toda la vida popular de su siglo. $\mathrm{Y}$ los grandes místicos fueron los mejores romanceadores de las ideas filosóficas y estéticas, en su época.

E1 padre Alfaro versificó para ilustrar al pueblo, sin ninguna ambición poética, por lo mismo el pulimento y retoque de sus poesías -que mucho hubiesen ganado-, quedaría para más tarde sin que se realizara después por falta de tiempo. Consecuentemente, su poesia es trasunto de su vida y

21 Luis de León. Aubrey F, Y. Bell. Barcetona. pág. 269.

22 Capitulos de literatura Española. Segunda merie. México 1945. psg. 186. 
explosión lírica, del inmenso amor que profesaba a la Virgen y a Cristo, con omisión de todo lo que no fuese este amor:

$$
\begin{aligned}
& \text { Pues ausente le lloras, pres ya muerto } \\
& \text { cual tortola le buscas con gemido, } \\
& \text { hax de mi pecho monumento } y \text { huerto } \\
& \text { de virtudes y dones tan florido, } \\
& \text { que de eate mundo inútil y desierto } \\
& \text { eche las anclas en un mar de olvido. }
\end{aligned}
$$

Y una vez más encontramos la influencia clásica en la preciosa imagen de la tórtola gemidora que revuela en el Cántico Espiritual de San Juan de la Cruz. 


\section{BIBLIOGRAFIA}

AlFARo NeRI, Lais Feljpe De. Las impresiones de sus obras pueden verae en $\mathrm{La} \mathrm{lm}$ prenta en México, de Jose Toribio Medina. Santiago de Chile. Impreso en 12 cane del autor. MCMX. Tomo v, pp. 151, 168, 483, 512.524.

Tomo v. pp. 112. 113, 130, 135, 169, 206, 219, 255, 348, 369, 390 . 512,630 .

Tomo vil, pp. 67, 323, 334, 369, 413.

Rejmpresiones del siglo XX son:

Las doce puertas abiertas de la Celestial Sion... Querétaro. Imprenta de Luis G. Pérez, calle de Miraflore núm. 17. 1848.

Reino piadonisimo ilustrado con nueve ciudades de Refugio...

Con las licencias necesarias. León. 1880. Tip. de J. M. Monzón, calle de la Plaza de Gallos núm. 36.

A le $m$ ds hermosa y salutifera Flor de los Campos... Reimpress con licencia de ordinario. Allende. 1895. Imp. Y Encuadernación de J. M. Larrea.

BeLl NUBRey, F. M. Luis de León. Barcejona.

CarreNo. Alberto Maria. Froy Miguel de Guevara. Mexico, 1921.

DIAZ DE GAMARrA, Benito. El Sacerdote Fiel y Según el Corazón de Dios... Queritaro. 1904.

DE LA MAzA, Francisco. San Miguel Allende. Instituto de Investigacionea Estéticaf. México, 1939.

LEÓN, Fray Luis De. Biblioteca de Autores Españolea. Madrid, 1855. Tomo 57.

Mentendez Pelayo, Marcelino. Historia de las Ideas Estéticas en España. Buenos Aires. 1943. Tomo II.

Mêndez Plancarte, Alfonso. Poetas Nowohispanos. Biblioteca del Estudiante Univertitario. Tomos 33 y 54 . 
Moreno VillA, José Leyendo . . Colegio de México, 1946.

Reyes, Alfonso. Capitulos de Literature Española. Segunda Serie. México, 1945.

SAN JUAN DE LA CRUZ. Obras Espirituales, Imprestion duodecima. Con licencia. En Sevilla, por Francieco Leefdael, en 1a Ballestilla, 1703 años.

SOR MArta DE Jesús. Mistica Ciudad de Dios. Primera parte. Año de 1698. Con lícencia. En Sevilla: por Juan Francisco de Blas. Impresor mapor de dicha cindad.

VAlbuens y PrAt. Angel. La Vida Española en la Edad de Oro, Bancelona. 1943. 
POESIAS DEL PADRE luIS FELIPE NERI DE ALFARO

\section{LAS TENTACIONES DE CRISTO}

Ufano con sus bélicos ardides en piedras da el contratio sus combates, no viendo que lo inclito Davides con nnz sola postran los Goliates. Ya ee acerca el dragón al sacro Alcides que adoran los olimpicos penates, y annque teme invadir héroe tan fuerte. in embargo, le dice de estz suerte:

Si eres bijo de Dios haz un portento que el mundo to celebre $y$ yo lo estime convirtiendo estas piedras en suatento de dulce pan que tu flaqueza anime. IOh necia ceguedad de sippid eangriento! . lqué otra cosa ejecuta un Dios sublime que bacer pan de las piedtas cuando... de oro trillado el campo ameno llena!

Yo (responde) de pan no necesito. que otro pan invisible me alimenta: la palabra de Dios, con que acredito 12 gracia que mis méritos alienta. $Y$ en el eacro volumen ext́́ excrito que el hombte no tan sollo te sustenta con el pao, mas también con las lexcionea que dan de Dios los misticos sermones.

Vencidos ya, otra vez el basilisco conduce al Salvador al alto templo 
Y uobre el chapitel de au obelisco coloca el raro de bumildad ejemplo. Arrojate (le dice) de ese riaco, que i a ewcuadronet de ángeles contemplo en voz de la Escritura, que aro manos previenen a tus miembros soberanos.

E1 Señox con hermosa antilogía le rexponde que el mistico volumen. prohibe tencax con bárbara osadia la majestad del soberano numen. Aqui lleso una $Y$ otra jerarquia. F en ecroe panegiricoa preaumen. celebrar de Jestís estas victorizs rindiendo teverencia a las trea gloxias.

E1 soberano Padre que previno tue ojos a espectículo tamaño. admirado del trinnfo peregrino, al Hijo celebró con gozo extraño. $Y$ viendo aquel expejo cristalino que no exlipsob del śspid el engaño. manda a los nueve luminotos coros le sirvan de la tierta los tesoros.

Trianf6 el Señor $y$ el aspid vergonzoso armado de furor voela a la cumbre donde mostró en diseño artificioso de los orbes la ismenar peadumbre. Toda eta pompa de esplendor gloriowo que ontenta (dice) en una $Y$ otra cumber, un imperio te (doy), si reverente idolatras las luces de mi oriente.

jOh insolencia de espirita nefando! za Dios le pides cultos, a un ascuro qué ha de venerar el Setior cuando es trono de an gloria el cielo puro? ¿Aquél de quien ti oreo estí temblando? LAquél que el Orión formó $\$$ Artuto? ¿Aquella eterna luz inaccesibie? ¿Aquds abismo siempre incomprentible? 


\section{CRISTO EN LA CRUZ}

Ya el León, que la sierpe figuraba, levantado se mira en aquel leño, que ba de servirle de gloriosa clava para postrar del basilisco el ceño.

$1 \mathrm{Ob}$ prodigiosa cruz. Divina aljabz que invento el más glorioso desmpetio del amor, cuya dalce tirania de su hiel, formb al hombre, ia ambrosial

Tú eres la lira del divino Orfeo que mueves ya a los troncos $y$ a las fieras. que ya deshechas con tu canto. veo. las leyes del infierno más severas.

iOb glorioso estandarte, alto trofeo que suspende las nitidas esferas viendo 1a vara, que a Moisks previno el dulce encanto del Amor divinol

IOh frbol del Paraiso portentoso. gunca bastantemente celebrado. enyas bojas con Frirmaco dichoso del veneno del Angel rebeladol

Verás del mundo el tmbito glorioso. en tus altos encomios conspirado, en tantas bocas, coantas eon las fuentes que ilustran to Epiciclo en cuatro Orientes.

\section{MILAGROS DEL AGUA Y DEL VINO}

Dime ya tú, Deipara Divina. los Milagros, que tu Jerts precioso. para estas sacras bodas predestina con que honrat a la esposa y al esposo:

Conviértese ya el agua criatalina en el licor del vino generoso, que (saca) admiraciones a mi plectro el dulee de loa śngeles electro. 
Ya la vid verdadera fructifica el néctar de sul ramo exprimido. en la feliz Cans donde alambica dulces glorias el pimpano florido.

Purpureo vino es ya cuanto rabrica. a cayo bonor se mira reducido el líquido elemento cuya forma en gloria. de María se transforma.

El cándido licor gustoso admite el toudo matiz. I los cristales aguel sabor reciben, que compite las dulces ambrosias celeatiales.

$X$ tanta inundación es lea permite, que sobraron los fértiles randales, inundando las meas y parede: de aquel néctar que sirve Ganimedes.

\section{MULTIPLICACION DE LOS PANES Y PROMESA' DE LA EUCARISTIA}

Moisé, primero, el Salvador Divino. el trigo de Belén amante aplica al apuno esuadrón a quien previno cuantos Panes ou gracia multiplica.

Que si el feliz maná del cielo vino a dar al hombre cuanto el gusto explica, hoy el Pan de los íngeles ofrece el símbolo mayor que le engrandece.

Comió toda la turba y low fragmentos redundaron en cfndido cofinos. celebrando tan íaclitos portento en dulces liras canticos divinot.

Aqui absorta en tan altos sacramentos mi pluma se suspende en los destinos del Señor, viendo tanta luz (expresa) de aquel Pan, que hoy llustra nuestra meas.

No fué Moivé, (les dice el Rey Supremo) ('Oh alegórico Dios! ¿Quitin no te atiende?) quién dis el pan celeatial, que tanto extremo solo mi padre con en amor lo aprende. 
Vuentro mank, no preservó el extremo tírmino de 1a vida; Eota suspende 12 corrapción, que pan de entendimiento de los portentos se admiró el portento.

\section{LA MAGDALENA UNGE A JESUS}

¿Quién, pues, en tierno llanto no se muda viendo aquella (Maria) penitente que con Exomológetis profunda buecó la gracia y encontró la fuente:

Magdalena que en máquina profunda. de lígrimas ae outenta tan valiente. que el cielo asalta $y$ con $\mathrm{su}$ amor inmenso. al centro del amor deja suspenso?

Al tiempo que le inataba un fariseo 2. Jextin que aceptase su convite, llega a é una mujer que en torpe empleo de Phriné y Flora el ademin compite.

Maria, que magnífico trofeo (es) del gigante niño, cuando admite para supeditar los corazones. que vibre Magdalena sus arpones.

Inondados en llanto aus claveles, se postra reverente an decoro, dando a los pies del Salvador fieles el rico Ofir de sua madejas de oro.

Ya virve de (Pancaya) los vergeles en el fragante ungüento que el tesoro de so virtud, los nardos de sa fama, consagra a Cristo en amorosa llama.

\section{SONETO}

IOh Señora tan cola $y$ afligida! ¿A dónde to querido ha declinado? ¿A dónde está tn hijo tan deseado? ¿Dónde esta tu Jestas, th alma $y$ to vida? 
Si le quieren buecat. Madre queridh. en mi pecho le sengo espaltado. que annque groweramente le be tratado ya me in ando de llanto en la avenida.

Paez ausente le lloras, pues ya muerto. cual tórtola le buscas con gemido, haz de mi pecho monumento y brerto

de virtudes $y$ dopes tan florido. que de este mundo intatil y desierto eche las anclas en (un mar de) olvido.

A vos llego, Jerte, arrepentido, llorando amargamente mi pecado. mas viendo, vaje con ex Cruz cargado. tcomo no muero yo, que os he ofendido?

¿Cómo a mi corazón no lo han partido loa cambrones, que a Voe han coronado? Si, Jests. a Vou tienen traspasndo, muera yo de dolor sigviera berido.

Mas no, no muere yo, que tal consucio, no merece, quien fué tan inbumano: ¿pues que haré, mi Jesúa? a Vos apelo,

| válgame vuestro asilo Soberano I contra Vos he pecado, y contra el Cielo. perdonad a eate triste publicano.

Dulcíimo Jesús, Diok verdadero, Nazareno Divino, Hermoea Flor, mi Rey. mi Dueño, Padre y Redentor. a quien amo, en quien creo $y$ en quien espero.

Si al sacrificio váis, manso Cordero. veia aquí lo que roba vueatro amox, la Oveja soy perdida, Buen Pastor, coyas culpas cargatis, en el Madero;

Ya que asi me bnactis, me habeir de ballar, pues yo tambien os busco arrepentido. y espero, que me habéis de perdonar. 
Porque amor, $y$ dolor ane traēn readido y afí. ya Deeño mí, no mite pecar: perdín. joh mi Jesúst pendsa os pido.

\section{A LA VIRGEN MARIA (Dtcimas)}

iOh tórtola gemebunda, qué entendimiento ba de haber que pueda ya comprender vuestra pena sin acgunda! mas aunque sea tan profunda. baced que yo algo perciba $y$ vuestro Jeańs reciba con el corazón deshecho acramentado en mi pecho. ¿Con él muern. con ál viva!

Ya deponen del madero unos piadosos varones al que rasga corazones que es de aquel tronco cordero. Mas yo ya la considero. Virgen Maria, entre tus beazos. repasando sus despojos, arrojes por esos ojos el corazón a pedazos.

Ya dulcísima Maria. despierta vueatro querido, ya glorioso ha convertido vuestra pena en alegria. Gozaos, gozaos este día, $y$ pues repartis favore., doleos de los pecadores. que aman la Snma Bondad. $y$ a codos, Virgen, librad de las eternos horrores. 
TRADUCOION DEL STABAT MATER

(Fragmento en romance)

\author{
Estaba 1a Doloroea \\ Madre, de la craz al pie \\ mientras en el duro leño \\ mirabs a un bijo pender. \\ cuya snima gemidora \\ triste, dolorosa, fiel \\ el pnthal atravesó \\ de un angriento padecer. \\ IOh crín triste, afligida \\ catrvo aquella majer \\ i Madre bendita del Hijo \\ que tinico del Padre ex! \\ iQué inconsolable lloraba \\ Y temblaba, trixte al ver \\ de su fnclito hijo. penas \\ Tel mil de todo su bien t
}

\title{
A JESUS CRUCIFICADO \\ (Quintillas)
}

Saltidote rostro bermoes

de mi Jetút todo afeado, exupido y lantimado

Y por mi el color gracioso en amarillez trocado.

$Y$ venero tu cabeza venerable y lastimada con toda mi alma abrasada porque por mi con crudezz de eapinas fue traspasada.

Saitidote, soberana carne. a azotes rompidz fuiste, $y$ al fin de tu vida. 
te dió la gente inhomana hiel $y$ vinagre en bebida.

Y te salndo, costado sagrado de mi Señor, por cuya puerta el amor claramente lo bas mostrado que tienes al pecador.

Corazón sacto y divino, alecre cielo $y$ sereno. may deleitoso $y$ ameno. yo te saludo 7 me inclino a darte mi corazón, mi ser pleno.

Manos y pies que clavados fuisteis por (mi redención) Y en roja angre bañados, de mí veréia adorados con el labio y corazón.

Mi Jestis, por tus agrada* llagas floridas te pido. queder en el mio excondido $y$ por tus pies estampados.

\section{VIA CRUCIS (Déciman)}

\section{PRIMERA ESTACION}

Áqui con ctüel rigor aquellos ministros crueles, con abrojos, con cordeles, azotan al Salvador.

Con espinas (iqué dolor!)

le corona la inclemencía, y aquí la inicua sentencia di $\delta$, tirano $e$ insolente. el aleve presidente contra la suma inocencia. 
I AY mi Dios que en esas penas

que os acerent a la muerte

para ataros de esta sperte

mi yerro dió las cadenast

De vuetra virtud ajenat

oon: a mi me las pasad

las de mi culpa quitad.

Reo parecét siendo juez. pues haced qoe a mi altiver

humille vectern bumildad.

\section{SEGUNDA ESTRCION}

Alma, aquí el dulee Jesús.

de aquel mirmol deatado.

para cargar ta pecado

abraza amante on cruz.

La perpura que a la laz,

por mofa al odio vistis.

ernel le deanuda $y$ volvis

a cefirle ia corona,

Y en cada herida pregona

que a tu nolud puerta abrib.

¿Ay. Sefiorl, ¿Quín wino yo

on cargó ene duro peas?

Eve tommento confiewo

que mi calpa os lo canes.

Contra vo el grito alzó

$y$ de mante os dís entencia:

pres rexigne mi obediencia

a vueatra ley. $y$ contrito.

afqueme de mi delito

Ia cruz de la penitencia.

TERCERA ESTACION

Aquí tin aliento $y^{2}$

porque it culpa le abruma.

aquella majeatad mama

la primer caída da.

Abatido en tierra exts

arrojando de las venas

futntes de pfrpera llenas.

puet al solpe que le dieron 
Ilagas $\%$ beridas se abrieros para aumentarle aus penat.

1 Asi abatido mi Dios 1 Alzad, mi rey soberano. que porque me deis la mano os doy yo la mano a roa. Cafateis (con) peso atron de mi delito, $y$ así

baced que el dolor aqui The acabe. No desprecicia mi llanto puew. (ae) que caet para Jevantarme a mi.

\section{CUARTA ESTACIOW}

De Hijo y Madre aqui lqué penal . (we encuentra fino) el anot: Jesti lleno de dolor Maria de congoja llena.

$A$ ambos la angustia enajena en tormento tan atroz: ma viendo María que a Dioo le bacen tan crueles agravios. suple a la roz de son labios de sus lágrimas la voz.

i Ay. Señora, ese conflicto que ta pecbo ba tranpasado mi delito lo ha canaado! i Maldito sea mi delitol $Y$ a de mi culpa contrito te acompaño en tu quebranto:

a ti me acojo: por canto. solicitame el perdon. que ya de mi alma el borrón lavo con amarto llanto.

\section{QUINTA ESTACION}

Sigaiendo a lou dos ladrone: va Jeadi con paso lento, agobizdo al cruel tormento de martirion $y$ baldones. $Y$ temiendo los enyones. . que se impida su trofeo. 
para lograr so deaco de que muera en ona cruz. por aliviar a Jesús : alguilan a un Cirineo.

iAy. mi Jesús, qué aflicción desmaya así nuestro cielo 1 IQuién para daros consuelo fuera regundo Simónl. Sáqueme vuestra pasión de mi culpa. Señox, hoy que firme palabra os doy. si salgo de aqueste abismo, que negándome a mí mismo publique que voestro soy.

\section{SEXTA ESTRCION}

Aquel rostro eneangrentado limpia con piedad no poca una mujer, y en su toca queda amante retocado; el triplicado traslado le paga el divino amor: con el pincel del dolor le pinta imágenes tres: y por piadoea, esta vez. toca en an toca el favor.

i Ay. mi Jestas, ya en el lienzo de mi alma ingrata $y$ manchada. veo con la culpa bqrxada la imagen del Str inmenso:

(mas ya) retocarla pienso: Vos, mi Jeaus, me ayudad: vuestra clemencia empefiad. prevengan vueatros favores en vaestra sangre colores. pincel en vuestra piedad.

\section{BEPTMM ESTACION}

\section{Vese Jests pormguido} de aquel vulgo caraicero: con el pewo del malero. caý job rigor! afripido. 
Mofado y escaraecido eatí de la chusma infiel:

Alma, en tormento tan cruel, mira, por tu culpa atroz. postrado al Hijo de Dion por librarte de Luzbel.

Rendido al leño oneroeo os veo. Sefiot lqué impiedrat $y$ fuera de la ciodad arrojado coal leproso. ¡Qué paso tan doloroso. mi Jeśrs, al alma es totre! Mín es la lepra. pues apreate. vuestro amor la medicina $y$ aquesa triaca divina cure en mi la mortal peste.

\section{OCTAVA ESTACION}

Con afligido lamento, de unas mujeres el llanto de Jesús siente el quebranto y llora el duro tormento: enéfinales entimiento, Jesís 2 su corazón. 7 les manda en su aflicción que apliquen aquel gemido sobre sus calpas, que han tido la causa de au pasión.

IAy, dulce Jeaús, que a mit me habéis piadoso enseifindo a que llore mi pecado, pues por él pentis asi! Ya lo hago, Señor, puea di motivo con mis arrojos Y a esos divinos enojos: Y pues en mí no hay dixulpa, sean para llorat mi culpa todos mis sentidos ojos.

\section{NOVENA BSTRCTON}

Yo en el repecho fragow, de aquel monte con ta eruz. 
aquil otra vez cae Jestis, triste, afligido $Y$ llorono: alzare prueba animoso.

a caer vuelve desangrado: iAlma (ve) lo que bas coatado (ai) divino Dueño, pues (It) hace caer otra vea (el) peso de tu pecado:

Divino Sansón no estéis asi, que ya en tierno llanto. de mi culpa me levanto porque vos os levanteis. i Ay. Señor, no me dejéis! Inmenwo es vuestro poder ..... pues podeis bacer que aquenta alma ......

\section{DECIMA ESTACION}

Ya los verdugoe llegaron al monte con tu Criador. Alma. F aqui tque dolor! tiranos le desnudaron.

La corona la quitaron con rabia y enojo cruel. brindanle mirxada hiet porque recobre el aliento. Y en el madero sangriento expire inocente Abel.

Desnudo. Jesise, os miro sufriendo sonrojo tanto: ¿cómo no exbala mi illanto el alma en cada suspito? ¿qué espero, pues, que no expiro. al veron en tanca afrenta? Haced, dueño mio, que sienta de mi culpa el cruel letaryo. y bebz el cálix amargo de vuestra pasión sangrienta, 


\section{UNDECIMA ,ESTACION}

Aquí crueles e inhumanos. tendiendo en tierra el madero, al dulcisimo Cordero clavaron de pies $y$ manos. Nnnca más que ahora tiranos Io maltratan a porfía, crece alli la tirania, pues taladran de nna vez;

a Jestis manö $y$ pies y el corazón de María.

Señor. ppes mis yerros fueron los que así os despedazaron $y$ cuando al leño os fijaron

\section{DUODECIMA ESTACION}

Clavado el divino dueño, a impulso de la crueldad de una peña en la oquedad, fijan el pesado leño. Satisfecho ya su ceño mira el judaico rencot.

(Ya) Jesús muere 1 ob dolor!. y a embates de pena tanta bandera de paz levanta con su muerte el Redentor.

Mi Jesús. pues el cormento con mortales paxarismos entre penosos abismos

\section{DECIMATERCERA ESTACION}

Viendo que ar ausenta el día, Ia piedad sube a la cruz, y pasa de ella a Jesús, * los brazos de Maria. ¡Ay almal ¡CuÁl quedaría aquella pura criatura queriendo en cada rotura 
que miraba us aflicción.

a au triate corazón

datle amarga sepultura!

Es to sufrir invencible.

vueatra pena incomparable.

vestra anguatin inerplicable,

vteatro tormento indecible.

Reina afligida, zes posible

que mi Jesú: expiró?

Meerte mi culpa le dió,

ya advierto mi arrojo cruel.

I Sed mi abogada con bli

pues el agreacor sof yo.

\title{
DECUMACUARTA ESTACION
}

Ungido $y$ amortajado

quitan con afecto tierno

de aquel tegazo materno

el cuetpo despedazado.

De llantos acompañado

camina el entierro anto;

mas Jay! que en tanto quebranto

es fuerza en wa pecho noble

que el Ilanto a María le doble

el doble que ofrece el linnto.

CANCION Y GOZOS QUE SE CANTAN A LA MAS HERMOSA Y SALUTABLE FLOR DE LOS CAMPOS JESUS NAZARENO SENOR DE AGUACALIENTES

Porque de Ia Crux. Sex́or. hacéis florido el camino:

wis. Nazareno Divino.

Ja mate aluctable Flor.

\author{
Cual Flor del Campo exbalfio \\ toles fragancias 7 olores \\ que al campo $y$ todas sou floces, \\ en ellas aventajait. \\ Si a sanar vaie al V́ador. \\ coberano Peregrino: \\ cois, Nazartno Divino, etc.
}


Queréis caminar así, porque el Justo balle consuelo, I en Vou encuentre an Cielo como en Sagrado Alhelf : porque a su Cruz sobre amor, 1a Cruz el vuestro destino: Sois, Nazareno, etc.

Sois Narcioo, en la belleza, que os mirarei* en la Fuente de vuentra Sangre corriente, caando inclintit 1a Cabeza: fuentea son deI Salvador. las que vueatro amor previno: Sois, Nazareno. etc.

Soil del Cielo Maravilla. pues queda como pasmado, viendo, que a tan vil estado, su mirmo Criador humilla: Caminais, cual malhechor. porque asf al amor convino: Sois, Nazareno, etc.

Balesmina of retratais, porque vertis amoroes ece balmamo precioeo. conque a los hombres mantis: Blanco $y$ rojo. Flor de Aimor, Sois el Amante más fino: Sois, Nazareno, etc.

Sois Jacinto, no marchito, aunque mi amor on pondera. todo por dentro $y$ por fuera, en grandes Ayer eacrito:

Libro, que selta el dolor. - Flor libro o imagino: Soil, Nazakeno, etc.

Si vuestra Lengua enmadece, son bocas vuestras heridas que con lenguas muy floridas veentra caridad ofrece: Rtabricas graba el furor 
en la Flor, que de Alto vino:

Sois, Nazareno. etc.

Yo soy, decís, Instimado.

Row herida con espinas, soy entre las Clavellinas. como un clavel desbojado: soy Jazmin con anave olor. $y$ entre flores me reclino: Sois, Nazareno, ete.

Yo soy la Flor Imperial. a quien todo se anjeta, soy la morada Violeta, Lixio todo Cardenal : El golpe muda el color. como yo bien lo examino: Sois. Nazareno, ete.

Yo noy purptreo Granado, que tantas flores of rezco. cuantas heridas padezco. porque ace acabe el pecado: este brota el pecador, yexba que tanto abomino: Sois, Nazareno, etc.

Soy la Flor medicinal, wo el cindido Cordero. la mejor Flor del Romero, Y Azucena Celential: comunico mi candor. $Y$ bacia la tiexra me inclino: Sois. Naxateno, etc.

Soy el Adonia hermoso, de las flores envidiado $y$ inuerto por el pecado. que es Jabalí alevoso: vendido por un Traidor a dar mi vida camino: Sois, Nazareno, etc.

Alma, dame el corazbo. como a tu Flor más amada. y en ál quede colocada 
DOI: http://dx.doi.org/10.22201/iie.18703062e.1947.15.436

eata Flor de la Pasión:

ablande tanto favor

a ear pecho diamantino:

Sois, Nazareno, etc.

Porque de 12 Cruz, Sefíor,

bactis presente el camino,

cois. Nazareno Divino,

la mate caludable Flor 
DOI: http://dx.doi.org/10.22201/iie.18703062e.1947.15.436

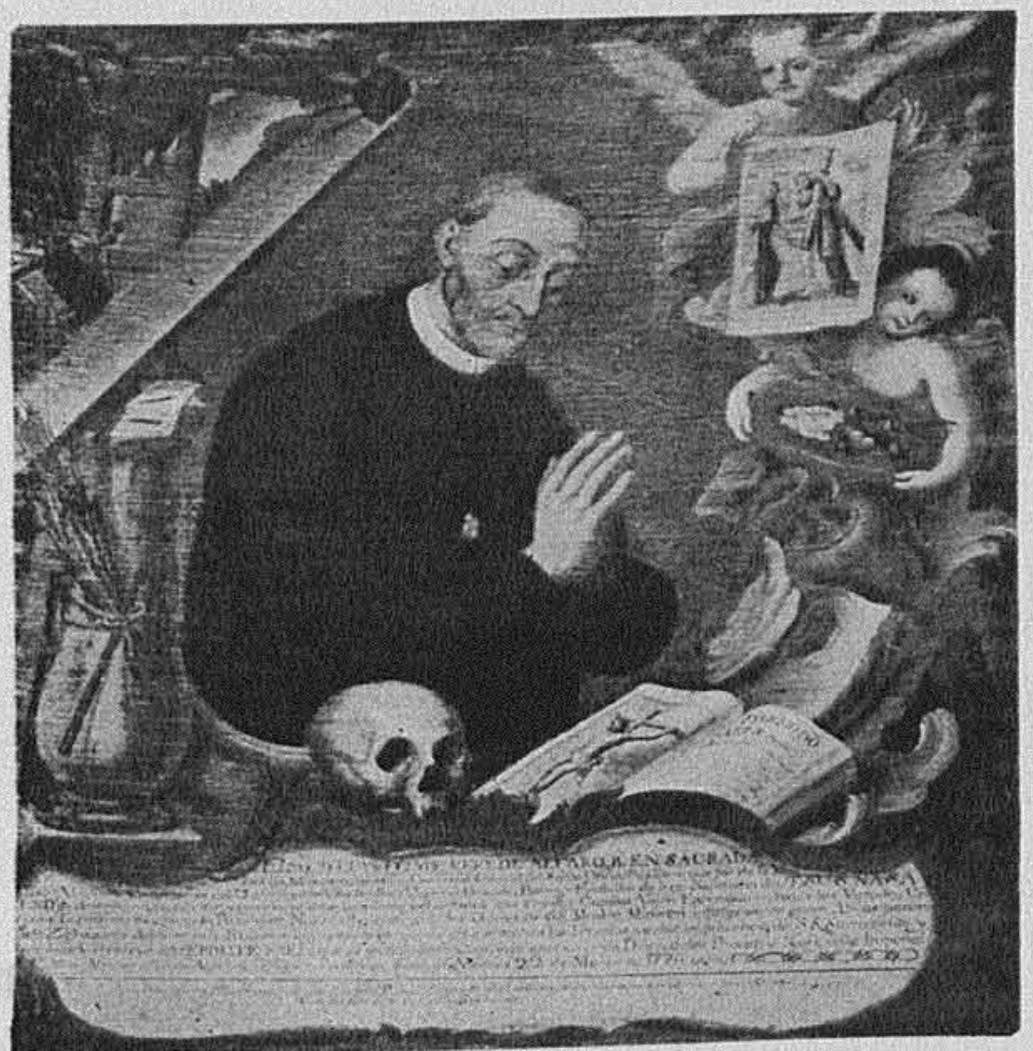

Fig. 1. Retrato alegórico post-mortem del padre Luis Felipe Neri de Alfaro, por Andrés de Islas. (Santuario de Atotonilco) 
DOI: http://dx.doi.org/10.22201/iie.18703062e.1947.15.436

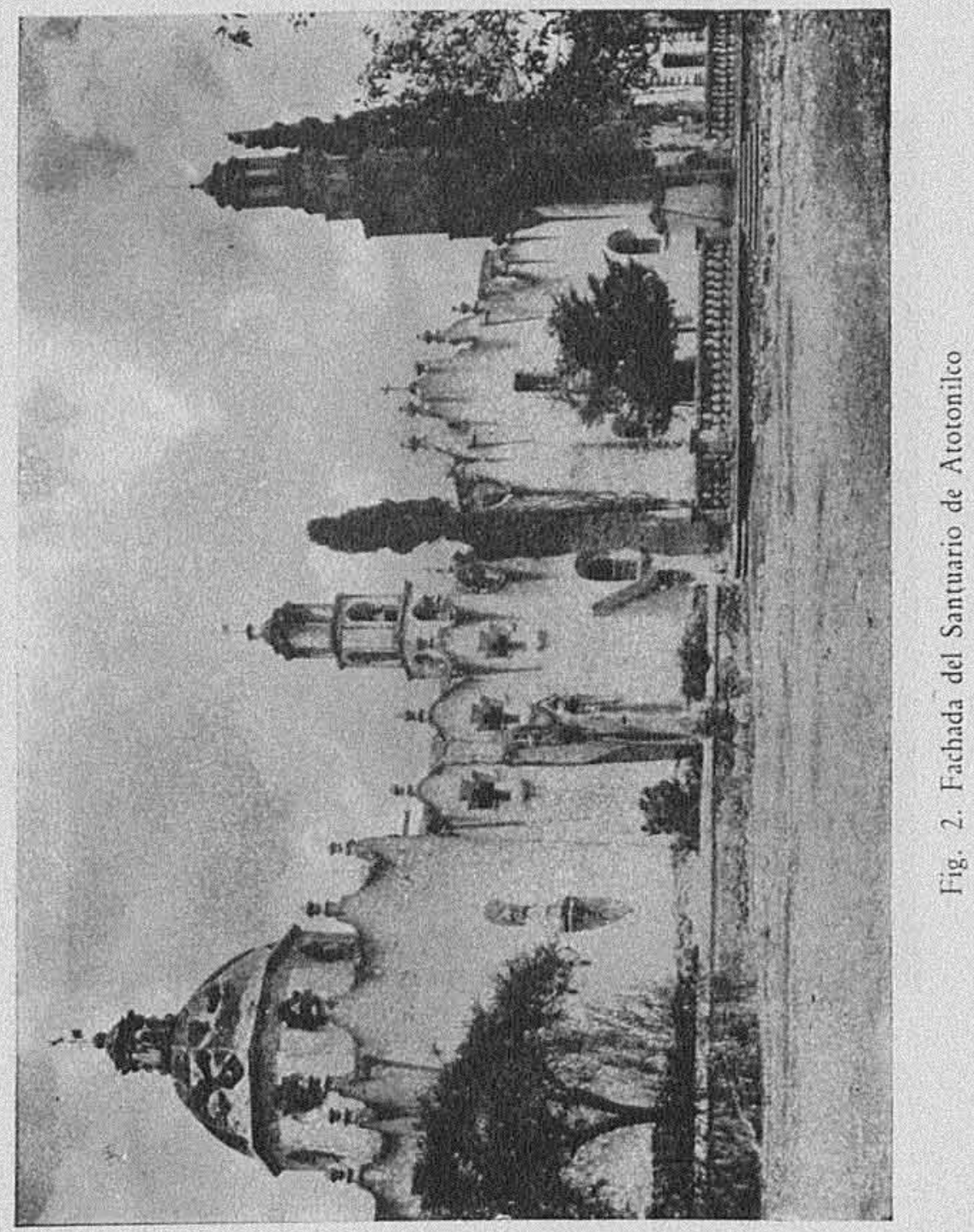




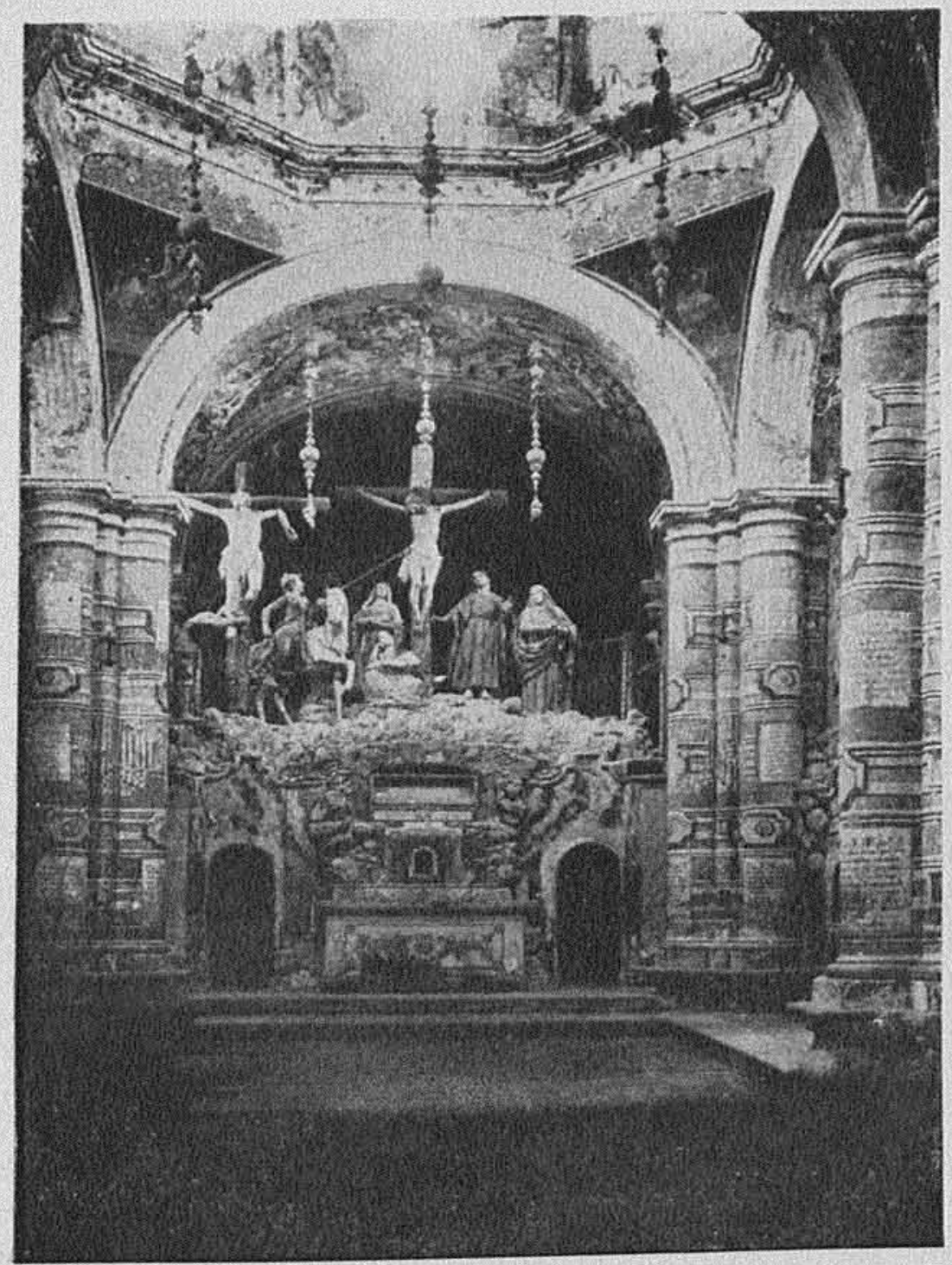

Fig. 3. Interior de la capilla del Santo Sepulcro del Santuario de Atotonilco con la mayoria de los versos de Alfaro escritos en los muros 